\title{
Effect of Sodicity on RWC, Proline and Yield of Different Rice (Oryza sativa L.) Genotypes
}

\author{
Nikita Nehal $^{1 *}$, A.H. Khan ${ }^{1}$, Nitish Sharma ${ }^{1}$, K.K. Mishra ${ }^{2}$, \\ Mayanker Singh ${ }^{1}$ and Sanjay Kumar Tripathi ${ }^{3}$ \\ ${ }^{1}$ Department of Crop Physiology, ${ }^{2}$ Department of Post-Harvest, NDUA\&T, \\ Kumarganj, Faizabad-224229, India \\ ${ }^{3}$ Department of Crop Physiology, CSAUA\&T, Kanpur-208002, India \\ *Corresponding author
}

\section{A B S T R A C T}

\begin{tabular}{|l|}
\hline Ke y w o r d s \\
Sodicity, Rice, \\
Biochemical, \\
Protein, Yield \\
\hline Article Info \\
\hline $\begin{array}{l}\text { Accepted: } \\
\text { 04 July 2018 } \\
\text { Available Online: } \\
\text { 10 August } 2018\end{array}$ \\
\hline
\end{tabular}

The present investigation was conducted in the net house of Department of Crop Physiology at Narendra Deva University of Agriculture and Technology, Kumarganj, Faizabad (U.P.). The experiment was carried out in pot culture in complete randomized block design with three replications and six rice varieties, (Three tolerant verities-CSR 36, CSR 43, Narendra Usar 3) and (Three susceptible-Swarna Sub 1, IR 28, IR 29) under sodic soil having $\mathrm{pH}$ 8.5-8.6, 9.0-9.1 and 9.5-9.6. Results of the experiments indicated that relative water content in leaves and protein content in leaves showed minimum reduction in all the tolerant varieties at $\mathrm{pH} 9.5$ in comparison to susceptible varieties at flowering stage of observation. Tolerant varieties have less accumulation of $\mathrm{Na}^{+}$and maintain better level of potassium at higher sodicity levels while, reverse in case of sensitive varieties. Yield components such as number of panicles plant ${ }^{-1}$ and test weight were higher even at higher $\mathrm{pH}(9.0,9.5)$ in all the tolerant varieties in comparison to susceptible varieties. CSR 36 and CSR 43 had a greater tolerance to sodic soil than IR 64 and IR 29.

\section{Introduction}

Rice is a staple food to feed more than 3 billion people and to provide $50-80 \%$ daily calorie intake to the world population (Khush, 2005). About 729 million tonnes rice per year is produced globally and 661 million tonnes of that is produced in Asia (FAO, 2012). Khan and Abdullah (2003) reported that rice crop identified as salt-susceptible both in seedling and reproductive stages. The seedling stage of rice, especially the root tissues, is very sensitive to salt stress (Zeng et al., 2001;
Yazdani and Mahdieh, 2012). Likewise, studies have demonstrated that fertility, seed set and grain production in rice were inhibited under salinity stress (Abdullah et al., 2001). Salinity is the second major obstacle to reduce rice production after drought condition. Selamat and Ismail (2008) reported that fifty per cent yield is being lost of the salt-sensitive rice genotypes due to salinity. Therefore, production of rice under saline condition is under pressure because salinity may cause plant demise, growth and development (Galvani, 2007; Roychoudhury et al., 2008) 
and reduced yield up to $50 \%$ (Zeng et al., 2002). Salt-affected soils are commonly distributed in arid and semiarid climatic zones and covered 1,307 $\mathrm{M}$ ha at global scale (FAO/IIASA/ISRIC/ISS-CAS/JRC, 2008). The largest areas of salt-affected soils are in Australia followed by North and Central Asia, South America and South and West Asia. An estimated area of $6.73 \mathrm{M}$ ha salt-affected soils are in India, of which $2.5 \mathrm{M}$ ha is in the IndoGangeticplain (Mandal, et al., 2011; National Remote Sensing Agency, 2008).

Water status is the major reason of growth reduction in plants under salt stress. Increasing salt in root zone reduces the water potential of leaf and subsequently, absorption of water and nutrients by plants are difficult or impossible (Romero-Aranda et al., 2001). Katerji et al., (1997) indicated a decrease in RWC and a loss of turgor resulted in limited water availability for cell extension processes. Based on the results of these researchers it seems there are two issues: (1) In high salt concentration, plants accumulate more $\mathrm{Na}+$ and $\mathrm{Cl}$ - in the tissues of the leaves than normal situation. Subsequently, by increasing $\mathrm{Na}+$ and $\mathrm{Cl}-$ within the leaf tissues lower osmotic potentials occurs and resulted in more negative water potentials and (2) Root hydraulic conductance reduction decreases the amount of water flow from the roots to the leaves, thus, causing water stress in the leaf tissues.

Accumulation of protein under salt condition may play a major role in terms of plants salt tolerance, where the proteins may serve as a reservoir of energy or may be adjuster of osmotic potential in plants subjected to salinity (Mansour, 2000). It has been concluded that a number of proteins induced by salinity are cytoplasmic which can cause alterations in cytoplasmic viscosity of the cells (Hasegawa et al., 2000). Ashraf and Harris (2004) noted that in salt tolerant cultivars of rice there were a high content of soluble proteins. Several researches showed that soluble protein contents of leaves decreased in response to salinity (Agastian et al., 2000 and Parida et al., 2002). Soluble protein increased at low up to moderate salt stress (Agastian et al., 2000).

Grain yield of rice in salt affected soils is much lower because of its high sensitivity to salt stress (Gaoet al., 2007; Ismail et al., 2007). Rice is exceptionally sensitive to salinity and sodicity at early seedling stage (Aslam et al., 1993) and high yield losses have been observed because of high mortality and poor crop establishment.

Modern high yielding varieties require considerable investment to ameliorate these soils to ensure reasonable yields, but this investment is beyond the capabilities of the resource-limited small holder farmers living off these salt affected areas.

\section{Materials and Methods}

The present investigation was carried out in the net house of Department of Crop Physiology, Narendra Deva University of Agriculture \& Technology, Kumarganj, Faizabad (U.P.) under pot culture during Kharif (wet season) 2015 and 2016 under sodic soil, with six varieties of rice viz., CSR 36, CSR 43, Narendra Usar Dhan 3 (salt tolerant), IR 28, IR 29 and Swarna Sub1 (salt susceptible). The experiment was conducted in earthen pots at $3 \mathrm{pH}$ levels (8.5-8.6, 9.0-9.1, 9.5-9.6) with six varieties CSR 36, CSR 43, Narendra Usar Dhan 3 (salt tolerant), IR 28, IR 29 and Swarna Sub1 (salt susceptible), thus the experiment consisted a total of 18 treatment combinations. The whole experiment was planned under complete randomized block design with three replications. Soil $\mathrm{pH}$ of various plots of Main Experiment Station (MES) of Narendra Deva University of Agriculture \& Technology, 
Kumarganj, Faizabad (U.P.) were tested and soil having $\mathrm{pH} 8.5,9.0$ as well as 9.5 were collected upto $15 \mathrm{~cm}$ depth (surface soil) and brought to net house of the Department of Crop Physiology. Soils were mashed and sieved to get it well pulverized before filling the pots. Uniform earthen pots of $12 \mathrm{~cm}$ diameter and $20 \mathrm{~cm}$ depth were used for this study. A small piece of stone along with cotton was put at the hole of the pot in the base for retaining of water in sufficient amount. After that each pot was filled with 8 $\mathrm{kg}$ of well pulverized dry soil. Before transplanting of seedling, soil $\mathrm{pH}$ of each pot was tested to confirm the $\mathrm{pH}$ of the soil.

Thirty five days old seedlings of all the 6 rice varieties were transplanted in earthen pots at 10 places. Ten days after transplanting five plants were maintained in each pot, two seedlings were used for transplanting. Six pots constituted a set for each variety at each $\mathrm{pH}$ value. In this way, each replication having 108 pots and treatments were replicated three times. Each pot was irrigated with 1 liter of water at an interval of one day to maintain the proper soil moisture for good growth. The relative water content (RWC) was determined by the method described by Turner (1981). Protein content in leaves was estimated by the method of Lowery et al., (1951). Number of panicles plant ${ }^{-1}$ was counted on three tagged plants per replication and their average was taken to express number of panicles plant ${ }^{-1}$. 1000 grains were counted from the samples of each treatment. These counted grains were weighed and recorded as test weight at $15 \%$ moisture level.

\section{Results and Discussion}

It is evident from the data that the relative water content of plants reduced with the increase of $\mathrm{pH}$ levels at all the growth stages of observation (Table 1). However, the reduction was less in tolerant varieties (CSR
36, CSR 43, Narendra Usar Dhan 3) as compared to susceptible varieties (IR 28, IR 29, Swarna $S u b$ 1) at all the growth stages. Maximum RWC was recorded in CSR 36 followed by CSR 43 and Narendra Usar Dhan 3 while minimum was found in IR 29 at all the growth stages. The effect of $9.5 \mathrm{pH}$ was more severe as compared to lower $\mathrm{pH}$ levels (8.5 and $9.0 \mathrm{pH}$ ). The mean effect of variety and treatments was found significant, while the interaction effect was found non-significant at all the stages of observations. This result are in accordance with the findings of Chutipaijit et al., 2009 and Amirjani, 2010 also reported that tolerant varieties maintained higher relative water content under salinity stress with respect to sensitive varieties. The increase in relative water content might be due to increase in osmotic pressure of cytoplasm which is accompanied by the synthesis of osmolytes which ultimately enhanced water flow into two plant organs.

The data pertaining in Table 2 show that protein content decreases with the increase of $\mathrm{pH}$ level of all the varieties but maximum decrease was observed at higher $\mathrm{pH}(9.5 \mathrm{pH})$ as compared to that in lower $\mathrm{pH}$ levels $(8.5$ and $9.0 \mathrm{pH}$ ) at all the stages in all the varieties. At all the stages of observation maximum protein content in leaves was observed in CSR 36 followed by CSR 43, while IR 29 showed minimum protein content followed by IR 28 at all $\mathrm{pH}$ levels. The mean effect of variety and treatment was significant at all the stages of observation, whereas, interaction effect was found non-significant at all the stages of observations. Exposure to salinity can result in denovo protein synthesis or an up-regulation of the process to increase the concentration of certain proteins already present in the plant (Singh et al., 1987). Proteins accumulating in plants grown under saline conditions act as a storage form of nitrogen which is re-utilized in absence of stress (Jha and Singh 1997, Akbar et al., 1972 and Akbar and Yabuno, 1975). 
Table.1 Effect of sodicity on relative water content (\%) in leaves of different varieties of rice at flowering stage

\begin{tabular}{|l|c|c|c|c|}
\hline \multicolumn{1}{|c|}{ pH } & $\mathbf{8 . 5}$ & 9.0 & 9.5 & Mean \\
\hline Variety & & & & 83.60 \\
\hline Narendra Usar Dhan 3 & 84.82 & 83.85 & 82.14 & 87.15 \\
\hline CSR 36 & 88.16 & 87.38 & 85.91 & 85.18 \\
\hline CSR 43 & 86.30 & 85.41 & 83.83 & 78.61 \\
\hline Swarna Sub 1 & 79.74 & 79.35 & 76.74 & 76.77 \\
\hline IR 28 & 78.78 & 77.16 & 74.37 & 72.35 \\
\hline IR 29 & 74.90 & 72.57 & 69.59 & - \\
\hline Mean & 82.11 & 80.95 & 78.77 & \\
\hline SEm & & $\mathrm{V}=0.39, \mathrm{~T}=0.27, \mathrm{~V} \times \mathrm{T}=0.67$ & \\
\hline CD at 5\% & & $\mathrm{V}=1.11, \mathrm{~T}=0.79, \mathrm{~V} \times \mathrm{T}=\mathrm{NS}$ & \\
\hline
\end{tabular}

Table.2 Effect of sodicity on protein content ( $\mathrm{mg} \mathrm{g}^{-1}$ fresh weight) in leaves of different varieties of rice at flowering stage

\begin{tabular}{|c|c|c|c|c|}
\hline $\begin{array}{ll}\text { Variety } & \text { pH }\end{array}$ & 8.5 & 9.0 & 9.5 & Mean \\
\hline Narendra Usar Dhan 3 & 8.63 & 8.19 & 7.38 & 8.07 \\
\hline CSR 36 & 9.79 & 9.45 & 8.78 & 9.34 \\
\hline CSR 43 & 9.27 & 9.67 & 8.95 & 9.30 \\
\hline Swarna Sub 1 & 7.71 & 7.13 & 6.21 & 7.02 \\
\hline IR 28 & 6.84 & 6.14 & 5.08 & 6.02 \\
\hline IR 29 & 6.23 & 5.38 & 4.12 & 5.24 \\
\hline Mean & 8.08 & 7.66 & 6.75 & - \\
\hline SEm \pm & \multicolumn{4}{|c|}{$\mathrm{V}=0.23, \mathrm{~T}=0.16, \mathrm{~V} \times \mathrm{T}=0.40$} \\
\hline CD at $5 \%$ & \multicolumn{4}{|c|}{$\mathrm{V}=0.66, \mathrm{~T}=0.47, \mathrm{~V} \times \mathrm{T}=\mathrm{NS}$} \\
\hline
\end{tabular}

Table.3 Effect of sodicity on number of panicles plant ${ }^{-1}$ in different varieties of rice

\begin{tabular}{|c|c|c|c|c|}
\hline $\begin{array}{ll} & \mathrm{pH} \\
\text { Variety }\end{array}$ & 8.5 & 9.0 & 9.5 & Mean \\
\hline Narendra Usar Dhan 3 & 8.01 & 7.68 & 7.21 & 7.63 \\
\hline CSR 36 & 9.79 & 9.67 & 9.41 & 9.62 \\
\hline CSR 43 & 8.14 & 7.98 & 7.59 & 7.91 \\
\hline Swarna Sub 1 & 6.80 & 6.39 & 5.68 & 6.29 \\
\hline IR 28 & 6.61 & 6.11 & 5.25 & 5.99 \\
\hline IR 29 & 5.21 & 4.52 & 3.47 & 4.40 \\
\hline Mean & 7.43 & 7.06 & 6.44 & - \\
\hline SEm \pm & \multicolumn{4}{|c|}{$\mathrm{V}=0.13, \mathrm{~T}=0.09 \mathrm{VxT}=0.22$} \\
\hline CD at $5 \%$ & \multicolumn{4}{|c|}{$\mathrm{V}=0.37, \mathrm{~T}=0.26 \mathrm{VxT}=\mathrm{NS}$} \\
\hline
\end{tabular}


Table.4 Effect of sodicity on number of test weight (g) in different varieties of rice

\begin{tabular}{|c|c|c|c|c|}
\hline $\begin{array}{ll}\text { Variety } & \mathrm{pH}\end{array}$ & 8.5 & 9.0 & 9.5 & Mean \\
\hline Narendra Usar Dhan 3 & 22.46 & 21.85 & 20.77 & 21.69 \\
\hline CSR 36 & 23.25 & 22.76 & 21.78 & 22.60 \\
\hline CSR 43 & 24.21 & 23.84 & 23.05 & 23.70 \\
\hline Swarna Sub 1 & 19.82 & 18.61 & 16.80 & 18.41 \\
\hline IR 28 & 20.85 & 20.10 & 18.84 & 19.93 \\
\hline IR 29 & 20.27 & 19.25 & 17.64 & 19.05 \\
\hline Mean & 21.81 & 21.07 & 19.81 & - \\
\hline $\mathrm{SEm} \pm$ & \multicolumn{4}{|c|}{$\mathrm{V}=0.16, \mathrm{~T}=0.11 \mathrm{VxT}=0.28$} \\
\hline CD at $5 \%$ & \multicolumn{4}{|c|}{$\mathrm{V}=0.46, \mathrm{~T}=0.32 \mathrm{VxT}=\mathrm{NS}$} \\
\hline
\end{tabular}

Protein synthesis is also destined to play an active role in osmotic adjustment. A significant increase in protein content and positive correlation has been ensured in tolerant rice seedlings compared to the sensitive ones.

The perusal of the data of number of panicles plant $^{-1}$ presented in Table 3 clearly indicate that no. of panicles plant ${ }^{-1}$ decreased with the increase in $\mathrm{pH}$ level. The effect of higher $\mathrm{pH}$ levels $(9.0$ and $9.5 \mathrm{pH})$ severely reduces the number of panicles plant ${ }^{-1}$ in all the varieties as compared to lower $\mathrm{pH}$ level $(8.5 \mathrm{pH})$.

The tremendous decline in number of panicles plant ${ }^{-1}$ were observed due to high sodicity as a result mean effect of treatment showed 6.44, 7.06 number of panicles plant ${ }^{-1}$ at 9.5 and 9.0 $\mathrm{pH}$ respectively against 7.43 panicles plant ${ }^{-1}$ at $8.5 \mathrm{pH}$.

Among all the cultivars grown under different $\mathrm{pH}$ levels maximum number of panicles plant ${ }^{1}$ was noted in CSR 36 followed by CSR 43 and Narendra Usar Dhan 3 at all $\mathrm{pH}$ levels whereas, the minimum number of panicles plant $^{-1}$ was recorded in IR 29 and Swarna Sub 1 . The mean effect of variety and treatments was found significant whereas the interaction was found non-significant.
The data showed reduction in test weight in all the varieties with increased $\mathrm{pH}$ level however the effect of higher $\mathrm{pH}$ level (9.5 $\mathrm{pH})$ was found more detrimental as compared to lower $\mathrm{pH}$ levels $(8.5,9.0 \mathrm{pH}$ ) (Table 4). Among all the cultivars grown under different $\mathrm{pH}$ levels minimum reduction in test weight with increased $\mathrm{pH}$ levels was observed in CSR 43 followed by CSR 36 and Narendra Usar Dhan 3 while Swarna Sub 1 showed maximum reduction in test weight followed by IR 29 and IR 28 however among all the cultivars maximum test weight was noticed in CSR 43 at all $\mathrm{pH}$ levels whereas, the minimum test weight was recorded in Swarna Sub 1. The mean effect of variety and treatments was found significant however interaction was found non-significant. The negative effect of sodicity on the number of panicles plant ${ }^{-1}$ and test weight was not severe in tolerant varieties while the effect on susceptible varieties was more detrimental. The results of the study are in conformity with the findings of Zeng and Shannon, 2000.

\section{References}

Abdullah, Z., Khan, M.A. and Flowers, T.J. (2001). Causes of sterility in seed set of rice under salinity stress. J. Agron. Crop Sci., 187: 25-32. 
Agastian, P., Kingsley, S. and Vivekanandan, M. (2000). Effect of salinity on photosynthesis and biochemical characteristics in mulberry genotypes. Photosynthetica, 38: 287-290.

Akbar, M. and Yabuno, T. (1975). Breeding for saline-resistant varieties of rice. III. Response of F1 hybrids to salinity in reciprocal crosses between "Jhona 349" and "Magnolia". Jpn. J. Breed, 25: 215 220.

Akbar, M., Yabuno, T. and Nakao, S. (1972). Breeding for saline-resistant varieties of rice: I. Variability for salt tolerance among some rice varieties. Jpn. J. Breed, 22: 277-284.

Amirjani, M.R. (2010). Effect of $\mathrm{NaCl}$ on Some Physiological Parameters of Rice. EJBS, 3(1): 06-16.

Ashraf, M. and Harris, P.G.C. (2004). Biochemical indicators of salinity tolerance in plant. Plant Science, 166: 3-16.

Aslam, M., Qureshi, R.H., Ahmad, N., (1993). Mechanism of salinity tolerance in rice (Oryza sativa L.). In: Leith, H., Massoum, A.A. (Eds.), Towards the Rational Use of High Salinity Tolerant Plants. Kluwer Academic Publisher, Netherlands, 135-138.

Chutipaijit, S., Cha-Um, S. and Sompornpailin, K. (2009). Differential accumulations of proline and Flavinoides indica rice varieties against salinity. Pak. Jour. of Bot., 41(5): $2497-$ 2506.

FAO (2012). FAO says rice production outpacing consumption. http://www.fao.org/164713/icode/.

Accessed on 17 Nov. 2014.

FAO/IIASA/ISRIC/ISS-CAS/JRC. (2008). Harmonized world soildatabase (version 1.0). Rome: FAO.

Galvani, A. (2007). The challenge of the food sufficiency through salt tolerant crops. Rev. Environ. Sci. Biotechnol., 6: 3-16.
Gao, J.P., Chao, D.Y. and Lin, H.X., (2007). Understanding abiotic stress tolerance mechanisms: recent studies on stress response in rice. J. Integr. Plant Biol. 49: 742-750.

Hasegawa, P., Bressan, R., Zhu, J. and Bohnert, H. (2000). Plant cellular and molecular responses to high salinity. Annual Review of Plant Biology, 51: 463-499.

Ismail, A.M., Heuer, S., Thomson, M.J. and Wissuwa, M., (2007). Genetic and genomic approaches to develop rice germplasm for problem soils. Plant Mol. Biol., 65: 547-570.

Jha, B.N. and Singh, R. (1997). Physiological response of rice varieties to different levels of moisture stress. Ind. J. Plant Physiol., 2: 81-84.

Katerji, N., Van Hoorn, J., Hamdy, A., Mastrorilli, M. and Karzel E. (1997). Osmotic adjustment of sugar beets in response to soil salinity and its influence on stomatal conductance, growth and yield. Agricultural Water Management, 34: 57-69.

Khan, M.A. and Z. Abdullah (2003). Salinitysodicity induced changes in reproductive physiology of rice (Oryza sativa) under dense soil conditions. Environ ExpBot., 49: 145-157.

Khush, G.S. (2005). What it will take to Feed 5.0 Billion Rice consumers in 2030. Plant Mol. Biol., 59: 1-6.

Mandal, A. K., Obi Reddy, G. P., and Ravisankar, T. (2011). Digital database of salt affected soils in India using geographic information system. Journal of Soil Salinity and Water Quality, 3: 16-29.

Mansour, M. (2000). Nitrogen containing compounds and adaptation of plants to salinity stress. Biologia Plantarum, 43: 491-500. 
National Remote Sensing Agency. (2008). Mapping salt affected soils in India ( $\mathrm{p}$. 54). Hyderabad: Author.

Parida, A., Das, A. and Das, P. (2002). NaCl stress causes changes in photosynthetic pigments, proteins, and other metabolic components in the leaves of a true mangrove, Bruguiera parviflora, in hydroponic cultures. Journal of Plant Biology, 45: 28-36.

Romero-Aranda, R., Soria, T. and Cuartero, J. (2001). Tomato plant-water uptake and plant-water relationships under saline growth conditions. Plant Science, 160: 265-272.

Roychoudhury, A., Basu, S., Sarkar, S.N. and Sengupta, D.N. (2008). Comparative physiological and molecular responses of a common aromatic indica rice cultivar to high salinity with nonaromatic indica rice cultivars. Plant Cell Reports, 27: 1395-1410.

Selamat, A. and Ismail, M.R. (2008). Deterministic model approaches in identifying and quantifying technological challenges in rice production and research, and in predicting population, rice production and consumption in Malaysia.

Singh, N.K., Bracken, C.A., Hasegawa, P.M., Handa, A.K. and Buckel, S. (1987). Characterization of osmotin. A thaumatin-like protein associated with osmotic adjustment in plant cells. Plant Physiol, 85: 529-536.

Yazdani, M. and Mahdieh, M. (2012). Salinity induced apoptosis in root meristematic cells of rice. Int. J. Biosci. Biochem. Bioinform, 2: 40-43.

Zeng, L. and Shannon, M.C. (2000a). Effects of salinity on grain and yield components of rice at different seeding densities. Agron. J., 92: 418-423.

Zeng, L., Shannon, M.C. and Grieve, C.M. (2002). Evaluation of salt tolerance in rice genotypes by multiple agronomic parameters. Euphytica, 127: 235-245.

Zeng, L., Shannon, M.C. and Lesch, S.M. (2001). Timing of salinity stress affects rice growth and yield components. Agric. Water Manage, 48: 191-206.

\section{How to cite this article:}

Nikita Nehal, A.H. Khan, Nitish Sharma, K.K. Mishra, Mayanker Singh and Sanjay Kumar Tripathi. 2018. Effect of Sodicity on RWC, Proline and Yield of Different Rice (Oryza sativa L.) Genotypes. Int.J.Curr.Microbiol.App.Sci. 7(08): 118-124. doi: https://doi.org/10.20546/ijcmas.2018.708.014 